17S2-05 培養トロフォブラストを用いた胎盤関門における 薬物透過機構の解明

○宇都口直樹 ${ }^{1}$, 高橋剛視 ${ }^{1}$, 安河内郁恵 ${ }^{1}$, 尾崎菜穂子 ${ }^{1}$, 藤井まき子 ${ }^{1}$, 中島恵美 ${ }^{2}$, 渡辺善照 ${ }^{1}$

${ }^{1}$ 昭和薬科大学薬剂学研究室, ${ }^{2}$ 共立薬科大学薬剂学研究室

\title{
CHARACTERIZATION OF DRUG TRANSPORT MECHANISM ACROSS THE PLACENTAL BARRIER USING CULTURED TROPHOBLAST
}

${ }^{1}$ Naoki Utoguchi, ${ }^{1}$ Tsuyoshi Takahasi, ${ }^{1}$ Ikue Yasukouchi, ${ }^{1}$ Naoko Ozaki, ${ }^{1}$ Makiko Fujii, ${ }^{2}$ Emi Nakashima, ${ }^{1}$ Yoshiteru Watanabe

${ }^{1}$ Showa Pharmaceutical University, ${ }^{2}$ Kyoritsu College of Pharmacy

【目的】胎盤は，母体から胎児への選択的物質透 過の障壁として機能しており，これは胎盤関門と 呼ばれている．胎盤関門において，胎児の成長に 必須であるアミノ酸や糖類は能動的に透過するが, その他の物質は透過が制限されている.しかし， 一部の薬物は本関門を透過し，それらの中には胎 児に毒性や催奇性等の問題を生じるものもあり, 妊婦への薬物療法の安全性㹥確立されていないも のが多い，その原因として，胎盤関門における薬 物透過の詳細な機構がほとんど解明されていない ことが挙げられる。そこで，胎盤関門の本体であ ると考えられているトロフォブラスト層における 薬物透過機構を明らかにすることを目的に，今回 はジペプチド，葉酸およびデヒドロエピアンドロ ステロン硫酸抱合体 (DHEAS) の透過機構につ いて，ヒト由来の培養トロフォブラスト層を用い 検討した.

【方法】細胞：トロフォブラストとしてヒト choriocarcinoma由来BeWo細胞（clone b30）を 用いた1).

取り込䒠験：ジペプチド輸送系の評価に $\left[{ }^{14} \mathrm{C}\right]$ glycylsarcosine（Gly-Sar），葉酸輸送系 の評価に $\left[{ }^{3} \mathrm{H}\right]$ 葉酸および $\left[{ }^{3} \mathrm{H}\right]$ methotrexate

(MTX)，DHEAS輸送系の評価に $\left[{ }^{3} \mathrm{H}\right]$ DHEAS を用いた. BeWo細胞を12-well上に播種・培養 し，コンフルエント時に実験に供した. 培地を除 去後, 放射ラベルした薬物を添加し, 一定時間後 bufferを吸引除去後, 冷bufferにて洗浄し, 細胞 に取り込まれた薬物量を液体シンチレーションカ ウンターにて測定した。

透過実験 : コラーゲンコーティングを施した透過 チャンバー (Intercell ${ }^{\mathrm{TM}}$; クラボウ社) の膜上に BeWo細胞を播種，培養し，実験に供した。薬物 をapical側 (母体側) またはbasal側（胎児側）に 添加し, 経時的にその透過量を測定した.
【結果・考察】

ジペプ壬ド輸送：BeWo細胞における $\left[{ }^{14} \mathrm{C}\right] \mathrm{Gly}-\mathrm{Sar}$ 取り込みは，高濃度で飽和が認め られた。またエネルギ一代謝阻害剤（アジ化ナト リウム，2,4-ジニトロフェノール）により取り込 みの阻害が観察された.さらに $\left.{ }^{14} \mathrm{C}\right] \mathrm{Gly}$-Sarの取 り込みはジ，トリペプチドおよびジペプチド構造 類似薬物により阻害されが，アミノ酸，テトラペ プチドでは阻害を受けなかった (Table 1). BeWo細胞層における $\left[{ }^{14} \mathrm{C}\right]$ Gly-Sarのapical 側か らbasal側への透過は，過剩量のGly-Sar，セファ レキシンにより阻害された。 以上の結果から，ト ロフォブラストにジペプチド特殊輸送系が機能し ていることが示唆された.

Table 1 Effects of Various Peptides or Peptide-like Drugs on $\left[{ }^{3} \mathrm{H}\right] \mathrm{Gly}$-Sar Uptake by BeWo Cells a

\begin{tabular}{lc}
\hline Inhibitor & $\begin{array}{c}\text { Relative uptake } \\
\text { (\% of control) b }\end{array}$ \\
\hline Gly & $96.1 \pm 3.9$ \\
Gly-Leu & $31.9 \pm 2.6 \mathrm{C}$ \\
Gly-Pro & $40.7 \pm 3.2 \mathrm{C}$ \\
Gly-Sar & $47.3 \pm 4.2 \mathrm{C}$ \\
Gly-Gly-Gly & $62.8 \pm 4.5 \mathrm{C}$ \\
Gly-Gly-Gly-Gly & $101.3 \pm 8.3$ \\
Cephalexin & $18.6 \pm 7.1 \mathrm{C}$ \\
Cefadroxil & $52.3 \pm 11.4 \mathrm{C}$ \\
Captopril & $48.8 \pm 3.7 \mathrm{C}$ \\
\hline
\end{tabular}

a [3H]Gly-Sar uptake by BeWo cells was performed in the presence of $10 \mathrm{mM}$ of indicated agents.

b Each value represents mean \pm SD of four replicate experiments.

c $p<0.005$ vs untreated control (100\%). 
葉酸輸送: BeWo細胞における $\left[{ }^{3} \mathrm{H}\right]$ 葉酸の取り込 夕は高濃度で飽和が認められた。また $4^{\circ} \mathrm{C}$ 条件や エネルギー代謝阻害剤により取り込みの低下が観 察された。 さらに $\left.{ }^{3} \mathrm{H}\right]$ 葉酸の取り込夕は，過剩量 の葉酸, 構造類似体であるMTXや5-メチルテト ラヒドロ葉酸により阻害された。 Lineweaver-Burk plots解析により，葉酸の取り 込みをMTXが，MTXの取り込みを葉酸がそれぞ れ競合阻害していることが示された（Fig. 1). BeWo細胞層における $\left.{ }^{3} \mathrm{H}\right]$ 葉酸の apical 側から basal側への透過は, basal側から apical側への透 過に比べ有意に高かった．また $\left[{ }^{3} \mathrm{H}\right]$ 葉酸のapical 側から basal側への透過は過剩量の葉酸により阻 害された. 以上の結果から，トロフォブラストに 葉酸特殊輸送系が機能していることが示唆された。 In vivoにおいて，葉酸の胎児血中濃度は母体血 中のそれに比べ有意に高いことが知られているが， 本現象に，葉酸特殊輸送系が関与していることが 推察された.

DHEAS輸送系：エストロゲンなどのホルモン前 駆体であるDHEASは，胎児副腎で作られ，胎盤 でエストロゲンに変換される，さらに高濃度の DHEASは胎児毒性を示すことから，胎児側から 胎盤への輸送系が存在すると予想される. そこで BeWo細胞におけるDHEAS取り込夕機構を検討 した. DHEASのbasal側からの取り込みはapical 側からのそれに比べ有意に高かった. またbasal 側からのDHEASの取り込夕は過剩量のDHEAS により阻害された，以上の結果より，DHEASは 胎児から胎盤へ特殊輸送系を介して移行している ことが示唆された。 DHEASは有機アニオントラ ンスポータの一つであるOAT4の基質となること が報告されており，現在その詳細を検討中である.

\section{以上，胎盤関門には種々の特殊輸送系が機能し} ており，母体・胎児間の薬物移行・薬物動態を決 定付ける重要な因子として働いていることが推察 された.
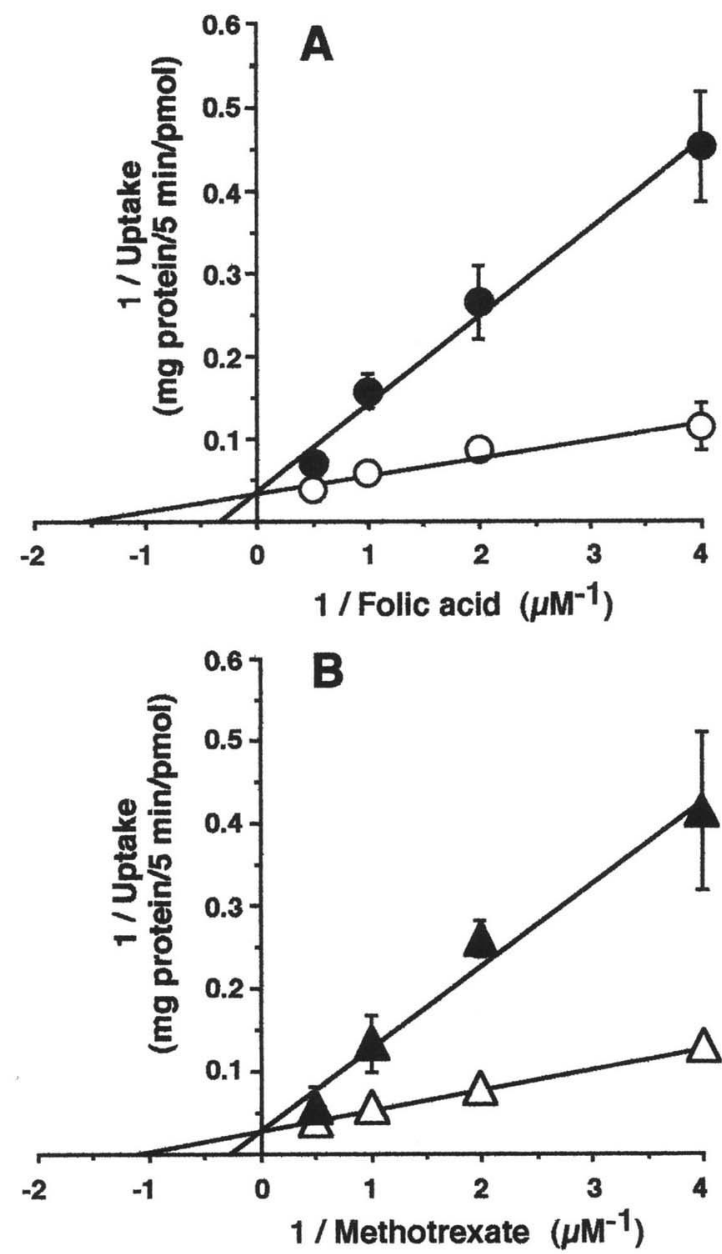

Fig. 1 A: Lineweaver-Burk plots of the uptake of folic acid by BeWo cells. Uptake was measured in the absence $(\mathrm{O})$ or presence of $2 \mu \mathrm{M}$ methotrexate (O). B: Lineweaver-Burk plots of the uptake of methotrexate by BeWo cells. Uptake was measured in the absence $(\triangle)$ or presence of $2 \mu \mathrm{M}$ folic acid $(\mathbf{\Delta})$. The vertical bar through each point represents the SD of four replicate experiments.

[ABSTRACT] Drug transport mechanism across the placenta is still unknown. The trophoblast that form the placental barrier have an important role in controlling the passage of molecules from mother to fetus. In this study, we investigated that dipeptide and folic acid are actively transported by transporters on the trophoblast. The human choriocarcinoma cell line, BeWo, was cultured on tissue culture plates. When the cells reached confluence, drug uptake experiments were performed. The uptake of $\left[{ }^{14} \mathrm{C}\right]$ glycylsarcosine $\left(\left[{ }^{14} \mathrm{C}\right] \mathrm{Gly}\right.$-Sar) by BeWo cells was saturated at higher concentrations. The metabolic inhibitors significantly inhibited the uptake of $\left[{ }^{14} \mathrm{C}\right] \mathrm{Gly}-\mathrm{Sar}$. In addition, various di- or tri-peptides inhibited the uptake of $\left[{ }^{14} \mathrm{C}\right] \mathrm{Gly}-\mathrm{Sar}$. The uptake of $\left[{ }^{3} \mathrm{H}\right]$ folic acid was saturable at higher concentrations and inhibited by metabolic inhibitors. Analogs of folic acid, methotrexate and 5 -methyltetrahydrofolate, inhibited the uptake of $\left[{ }^{3} \mathrm{H}\right]$ folic acid by BeWo cells. Kinetic analysis using Lineweaver-Burk plots revealed that methotrexate competitively inhibited the uptake of $\left.{ }^{3} \mathrm{H}\right]$ folic acid and folic acid competitively inhibited the uptake of $\left[{ }^{3} \mathrm{H}\right]$ methotrexate. The findings confirm that dipeptide and folic acid are transported by their transporters on BeWo cell monolayers. The dehydroepiandrosteron sulfate (DHEAS) uptake by BeWo cells from basal side of the cells was higher than that from apical side, and the uptake was inhibited by an excess amount of DHEAS. The findings confirm that the carrier of DHEAS exists on the basal membrane of BeWo cells. This work demonstrated the possibility of using a human monolayer-forming cell line, BeWo, to characterize putative trans-trophoblast transport mechanisms and their potential roles in controlling nutrients and drug across the placental barrier. [Reference] ${ }^{1)}$ Liu F., Soares M. J., and Audus K. L. Permeability properties of monolayers of the human trophoblast cell line BeWo. Am. J. Physiol., 273, C1596-C1604, 1997. 